\title{
CRITICAL SUCCESS FACTORS FOR COST MANAGEMENT IN PUBLIC- HOUSING PROJECTS
}

\begin{abstract}
Purpose

Effective cost performance is a crucial criterion measuring successful project management in Public-housing projects. This paper analyses the vital underlying factors surrounding the successful Cost Management Process (CMP) outcomes in Public Housing Projects (PHPs).
\end{abstract}

Design/methodology

The research was conducted in three stages. The first stage consisted of a detailed literature review to document Success factors affecting Cost performances and management. In stage two, Brainstorming sessions were undertaken with construction experts knowledgeable in cost management practices and have been involved in PHPs. These sessions were used to refine those Success factors for the PHPs settings and define their criticality with respect to the CMP stages using Interpretive Ranking Process (IRP). In Stage three, focus group sessions were performed to validate the interrelationships of the contextualised Success factors.

Findings

The top three most critical factors for successful implementation and outcomes at all CMP stages in PHPs settings were found to relate to competencies, team qualities and collaborative practices of Project Team (PT). Early contractor involvement and effective construction planning and management also emerged relevant to the process.

Practical implications

Government project departments, project managers and construction organisations (consultants and contractors) need to commit and mandate continuous development of cost management competencies for all professionals engaged in PHPs. Channels supporting Team integration and collaborative practices between design and construction teams are required to increase the likelihood of successful project cost management practice and outcomes in PHPs.

Originality/value

The research has developed a Factor-Process relationship model that can be used to improve and evaluate the efficacy of CMP implementation in PHP settings.

Keywords: Cost management, critical success factors, interpretive ranking process, project team, publichousing project, 


\subsection{INTRODUCTION}

Public Housing Projects (PHPs) are projects targeted at providing affordable housing to lowand low-middle income populations in many countries (Davies, 1997; Harris and Matthews, 2009; UN-Habitat, 2011). In many developing countries, PHPs represent one of the largest project-based areas of the construction industry (Ahadzie et al., 2008). These projects involve standardised design and construction of multiple housing developments in the same or several geographical locations executed under the same scheme, contract, and management systems (Adinyira et al., 2013). Besides, PHPs often employ prototype management practices that influence the operational and managerial framework for delivery. PHPs prioritise cost objectives considering rigid budgets (such as limited government funding), concerns on production price, and affordability requirements of project beneficiaries (Jacomit and Granja, 2011; Shrestha and Mani, 2013; McNelis, 2014). Therefore, PHPs require viable strategies and frameworks to ensure cost activities are managed efficiently throughout the CMP. Unfortunately, many Project Managers and Project Teams (PT) consisting of a Government Project department team, a Contractor team and a Consultant team are unable to deliver consistently, successful project cost outcomes as budgets are grossly overspent, negating realisation of set project objectives (Smith, 2014; Obi et al., 2015; Asiedu et al., 2017). Several reasons have been adduced for this failure, many of which revolve around the poor understanding of the underlying factors necessary for successful implementation within the Cost Management Process (CMP) stages. Thus, the significant attention found in the research on poor cost performance assessment (Kog and Loh, 2012), cost management systems (Obi et al., 2017; Doloi, 2011; Jacomit and Granja, 2011), process factors and success factors (Li et al., 2018; Lingard and Larsen, 2016). Doloi (2013) argued that identifying underlying success factors, and impediments for effective cost management is critical for achieving effective cost performances. Though he maintained that this process must be assessed from the perspectives of principally three key stakeholders: clients, contractors, and consultants, which constitute the PT.

As described in previous studies, success factors which lead directly or indirectly to successful outcomes are essential inputs in every management system (Chen, 2011; Kog and Loh, 2012; Wuni and Shen, 2020). Published studies (Kog and Loh, 2012; Enshassi et al. 2013; Cheng, 2014) espousing these factors are associated with team competencies and characteristics, management actions, project environment and procurement on cost management activities to mention a few. These underlying factors potentially impact on effective cost management 
process implementation hence the need to examine and understand their interrelationships as it affects the management process (Lindhard and Larsen 2016). Such assessment would lead to a list of process factors ranked in relation to their importance on the process stages and their effect on successful outcomes can be identified. The project managers and PT can then use the importance ranking to determine how to effectively plan, allocate and optimise limited resources to achieve the criteria and thus obtain project success within the PHP settings. However, despite extensive studies on CSFs, on cost performances and management (1) there is no explicit assessment of the CSFs for cost management in PHPs and (2) there is a lack of existing studies exploring and ranking the success factors with respect to the CMP stages and expected outcomes. These could be some of the reasons affecting cost management practices and the inability for construction organisations to train staff appropriately to engage and support in collaborative cost management practices in the PHP settings. As a result, there is a need to identify and evaluate the underlying factors critical for successful implementation and outcomes at various CMP stages in the PHP settings. This study leverages experts' views to analyse the underlying CSFs with respect to CMP stages in PHPs settings using an Interpretive Ranking Process (IRP). The study outcome is applicable to Project Managers and PT in that it will provide a Process-Factor analysis on how best to manage the CMP at each stage towards successful outcomes. Additionally, this research uniquely contributes to the knowledge of the CSFs for cost management practices in PHPs settings. The remaining sections of this paper are structured as follows: a literature review on the concepts of cost management and Success factors in construction; a justification of the methods deployed for data collection and analysis; analysis and results from the various Interpretive Ranking Process (IRP) step employed; discussion of key findings from the IRP, and finally, conclusions.

\subsection{LITERATURE REVIEW}

\subsection{Cost Management Process in Construction}

The ability to effectively manage project cost is a vital cornerstone of project management and a major Factor of project success (PMI, 2013) and PHPs are not an exception (Adabre and Chan, 2019). Cost management is defined as the process of planning, estimating, coordination, control and reporting of all cost-related aspects of a project to ensure project completion within the approved budget (Asworth, 2010; Krikham, 2015). Approaches to cost management practices require activities to ensure project resources are optimally utilised in the cost management process to achieve the required outcomes. These approaches are often similar 
across many countries because references are drawn from the Project Management Institute (PMI), or the Royal Institute of Chartered Surveyors (RICS) published standards. The cost management process, according to Kern and Formoso (2006), RICS (2012), and PMI (2013), consists of a set of interlinked procedures detailing the management of cost activities. As espoused by Kern and Formoso (2006), the CMP involves three stages: cost estimating, planning and control. The PMI (2013) Body of Knowledge identified the stages of the CMP as cost estimating, cost budgeting and cost controlling. The need to integrate a setting stage into the cost management process was advocated in previous studies (Zimina et al. 2012) and established in the new rules of measurement suites at the cost estimating stage (RICS, 2012). The above reviews on CMP suggest four main process stages, namely: cost setting, planning, budgeting and control and could be associated with the predesign, design, and construction phases of project delivery.

- Setting stage: This is the stage where the budget is set. It usually aligns with the preparation and brief stage of the project (RICS, 2012). Conventionally the project budget is the amount a client is willing to spend on the project after design development; however, in modern contemporary practice, following arguments towards cost and value performance improvement (Zimina et al., 2012) budgets should include target project cost before the design development.

- Planning stage: This stage is where the budget estimates are developed as the design undergoes development (Asworth, 2010). This stage involves a series of skills and adjustments to regulate and determine the elemental cost with a predetermined sum, in readiness for tender documentation. It usually aligns with the concept up to the technical design stages (RICS, 2012). Therefore, it involves an iterative procedure involving reviewing and updating the original budget estimate in line with up-to-date information.

- Budgeting stage: This stage is concerned with aggregating the estimated costs of individual activities or work packages into an authorised cost baseline (PMI, 2013). It usually aligns with the technical design stage (RICS, 2012). Mainly, project cost budgeting incorporates the allocation of resources to various work packages, along with a schedule to ensure that the project can be delivered within the expected cost limitations (Ashworth, 2010). The procedure involves estimation of costs, subsequent analyses, frequent revisions, and, to some degree, intuition through regular interaction among concerned parties.

- Control stage: This stage of the process is concerned with monitoring the status of the 
project to update the project budget, control changes that can negatively affect the cost baselines, and finally, reporting actual cost spent. This stage is carried out during construction. This will require proactive resource control and maintaining positive performances of cost activities (RICS, 2012; PMI, 2013).

Successful cost management outcomes are a cumulative product of effective practices maintained at each stage of the CMP. Scholars and practitioners have made reasonable attempts to identify specific performance indicators to measure the efficiency of cost management practice. Toor and Ogulana (2010) identified the efficiency of cost predictability, cost deviation alerts and effectiveness of cost and design decisions. More contextual to CMP stages, Jacomit and Granja (2011), and Zimina et al., (2012), identified the need for realistic target cost at the setting stage. Effective elemental cost targets are highlighted at the planning stage (PMI, 2013; RICS, 2012), while realistic operational cost baseline and positive cost performance indexes are recommended at the budgeting and control stage respectively (RICS, 2012; PMI, 2013). Studies by Kern and Formoso, (2006), Jacomit and Granja (2011), and Obi et al. (2017) further suggest that these CMP stages and indicators could also apply to PHPs. However the wielded influences of critical underlying factors for successful management process outcomes should not be ignored (Lindhard and Larsen 2016). Thus, the need to explore the CSFs for effective CMP implementation and outcomes.

\subsection{Success factors for cost performance and management}

Critical Success Factors (CSFs) or determinants have a significant impact on the effective and efficient system operation or outcomes when properly sustained, maintained, or managed (Chen et al., 2011; Kog and Loh, 2012). CSFs influence the quality of operations within any management system (Kog and Loh, 2012; Cheng, 2014). In this context, CSFs constitute the few management areas that must be given critical attention and resources commitment (Rockart, 1982) to guarantee successful cost management process outcomes in PHPs. In this context, these factors are required to maintain viable and effective operations within the CMP to achieve successful results at various stages. The literature documents CSF categories such as human, procurement, project environment and management-related factors. Asiedu et al. (2017) and Enshassi et al. (2013) argue that project environment-related factors are critical to successful cost management outcomes, especially in large and complex projects such as PHPs and especially in developing country settings considering the unstable political and economic 
conditions. However, Liu and Zhu (2007), Olawale and Sun (2010), Kog and Loh, (2012), and Obi et al., (2017) argue that human and management-related factors have a more substantial influence on cost management when compared to project environment-related factors. A variety of variables associated with cost performances and management on construction projects are documented in the literature.

Early studies by Trost and Oberlender (2003) identified six CSFs influencing cost estimating practices: basic process design, team experience, cost information, time to estimate, site requirements, bidding and labour climate. In a study of construction cost management in Hong Kong, Tang (2005) identified 10 CSFs crucial for effective cost management. These include: accurate material estimating, effective site management, realistic cost plan and tender budget, adequate funding, effective expenditure control, excellent communication within the PT, claims management, clear project brief, the experience of project type, and effective project planning. Liu and Zhu (2007), in a study in Australia, identified six key success factors for effective cost estimating practices: project information, team experience, cost information, estimating process, team alignment, and estimation design. Odusanmi and Onukwube (2008), in a study in Nigeria, identified the expertise of consultants, quality of information and flow requirements, PT experience, tender period and market condition, the extent of completion of pre-contract design, the complexity of design and construction, and availability of labour and materials as crucial CSFs for project cost estimating. Olawale and Sun $(2010 ; 2013)$ in a study of the UK construction industry identified effective and well-detailed project designs, effective risks and uncertainties management, effective project planning, effective management of project complexities, and effective subcontractor and supply chain management as CSFs for effective cost control practices. Kog and Loh (2012), in a study on cost performances in construction projects, scrutinised experts' views from 13 countries and identified realistic obligations, clear objectives, adequacy of plans and specifications, adequacy of funding, and project manager competency as key Success factors. Waziri (2012), in a study on cost estimating identified estimator's experience, expected accuracy, project scope definition, level of team integration, cost planning, effective communication, estimating methodology, historical data of similar contract, quality of cost data, and adequacy of resources as key Success factors. Enshassi et al. (2013), in a study in the Gaza Strip, identified ten key Success factors for cost estimating: material costs and availability, borders closure and blockade, PT's experience, experience and skill level of the consultant, detailed drawings and specifications, quality of information flow, completeness accuracy and reliability of cost information, currency exchange fluctuation, and clear contract conditions as crucial Success factors. Cheng (2014), in a study 
of cost influencing factors in Taiwan construction projects, identified 16 key cost-influencing factors of which clearly defining the scope of the project in the contract, cost control, and contract dispute (unclear drawings or guidelines/regulations) exerted the strongest influence. In a study of cost management in public construction projects, Okoye et al., (2015), identified realistic estimates and forecasting, early integration of PT continuous and effective communication, appropriate project delivery strategy, the commitment by team members to pre-established project objectives, and obtain buy-in from senior management as crucial factors. Smith (2016), in a study on 5-Dimensional Building Information Modeling (5D BIM) for cost management identified effective collaboration, communication, the commitment of client and PT, competent PT, continuous knowledge acquisition through training, comprehensive, and accurate design data as crucial Success factors. Asideu et al. (2017) identified government fiscal policies, effective project planning and supervision, accurate and well-detailed design and documentation, effective determination of contingency allowance, effective contract administration, competent PT, effective coordination amongst contractual parties, stable cultural and political environment, adequate and effective contractors' cash flow, and appropriate policy directives and strategies as critical factors of effective cost performance. Obi et al. (2017), in a study of housing projects in Nigeria, presented nine crucial Success factors for cost management: a well-developed client brief, detailed project designs and specifications, effective project planning and supervision, competent design team and contractor team, early contractor Involvement, effective team collaboration and commitment, adequate and timely funding, and timely resolution of land compensation dispute resolution. Sinesilassie et al. (2019), in a study of critical factors affecting cost performance in Ethiopian public construction projects, also identified the project manager's competence, scope clarity, owners competency, monitoring and feedback, coordination and communication among project parties, and quality control as key Success factors.

A number of CSFs $(n=54) \mathrm{s}$ shown in Table 1, were identified from the aforementioned studies which successfully utilised literature, questionnaires, interviews, or brainstorming sessions to establish the criticality of the Success factors for successful cost management practices and performances. These studies generically identify CSFs for cost performances or cost management practice without exploring the interrelationships of these factors with respect to CMP outcomes at all stages. Upon closer examination, cost estimating, which is only one stage of the CMP has attracted extensive studies. Although cost estimating is important, successful cost performance outcomes are hinged upon cost efficiency throughout the CMP. Furthermore, Adabre and Chan, (2019) argue that the CSFs for effective process management within PHPs are not precisely the 
same with other construction projects. Therefore, the need to investigate success factors for managing cost within PHPs setting can assist PTs in making more informed decisions towards improving and sustaining operational efficiency; a major feature of effective cost management practice. Hence, the critical research question to be answered in this paper is; what Success factors are crucial to supporting successful implementation and outcomes at various stages of the CMP in PHP settings? The remaining part of this study will try to establish the Success factors peculiar to CMP in PHP settings leveraging on expert views. Subsequently, the IRP is used to facilitate the ranking of the contextualised Success factors to the four stages of the CMP in PHP settings.

\subsection{RESEARCH METHODOLOGY}

The researchers have an interpretivist perspective, which involves constructing and creating knowledge based on the collective opinions of experts and participants (Fellows and Liu, 2015). This paper presents an interpretive based evaluation of Success factors for CMP implementation in PHP settings. The research was conducted in three main stages. The first stage reviewed and documented the CMP and variables with possible influences on cost management practice. This led to the development of an initial list of Success factors. Stage two engaged six construction experts (two each from Government housing project department, contractor, and consultancy organisations) in brainstorming sessions to refine and contextualise the identified CSFs for CMP in PHP settings. They also help define the dominance and interrelationships between the CSFs with respect to the CMP stages using the Interpretive Ranking Process (IRP). Brainstorming was considered most appropriate because it is arguably becoming the most widely used data collection technique for generating ideas, increasing creativity and problem solving with the ability to capture multiple iterations (Wilson, 2013). Considering the expected number of iterations (usually four and above) and need for consensus required in the IRP, individual creativity and ideation among participants was essential which would have been impinged upon using other methods such as Delphi and nominal group technique (Wilson, 2013; Sourani and Sohail, 2015). Finally, stage three engaged eight construction experts (two each from Government housing project department, contractor, consultant and two from academia) in a focus group discussion to validate the model. This approach was used to provide additional surety on the findings from stage two. Similar to Kog and $\log (2012)$, this differentiation is to enable a new insight from a PT perspective rather than just the quantity surveyors perspective. The experts who participated in the focus group and 
brainstorming sessions had extensive experience (minimum 15 years) in construction, and have been involved in PHPs and are knowledgeable and/or engaged in cost management activities at various stages of the CMP. Participants selected from these teams or organisations included quantity surveyors, construction managers, project managers and Architects. The countries or regions where these experts have worked or undertaken PHP include the United Kingdom, Nigeria, Hong Kong, South Africa, and India.

\subsection{IRP Methodology}

The IRP technique, according to Sushil (2009), is an expert dependent interpretive technique considered appropriate to examine the contextual interactions of a set of identified Success factors with respect to process stages/outcomes. Unlike other ranking techniques, such as Analytic Hierarchical Process (AHP) and interpretive structural modelling (ISM), IRP combines intuitive judgment, and rational choice process to create new knowledge during the ranking process that is useful for decision-making. For a detailed explanation on the IRP steps see Sushil (2009). Studies such as Luthra et al. (2015) and Haleem et al. (2012) have used IRP to analyse CSFs for green supply chain management and world-class manufacturing practices, respectively. They argue for IRP advantage over ISM as it examines factors with respect to their influence on process/ performance outcomes rather than contextual relations between the CSFs as with ISM. There are six main IRP steps employed in this research, as shown in Figure 1. Expert opinions were elicited through a series of brainstorming sessions and a focus group discussion to provide data for supporting and validating the IRP analysis and outcomes. The IRP results and findings are covered in the following sections.

\subsection{ANALYSIS AND RESULTS}

The results obtained following the IRP steps, as documented in section 3, are detailed below.

\subsection{Identifying the ranking and reference variables}

Experts reviewed the factors identified and refined them into 12 Success factors as listed in Table 2, which were considered the variables to be ranked represented by F1, F2 and F3...F12. There was a consensus among the experts concerning the applicability of the CMP stages to PHP settings and that, performance indicators highlighted are applicable to the process stages and were considered the variables that provide the basis for ranking represented by P1, P2, P3 and P4:

- P1= Setting stage to achieve realistic project target cost

- P2= Planning stage to achieve viable elemental cost targets 
- P3= Budgeting stage to produce realistic operational cost baseline

- P4= Control stage to deliver positive cost performance index

\subsection{Develop the interpretive, interaction and dominance matrix.}

Most respondents were familiar with the importance of the Success factors discussed and suggested that companies involved in PHPs need to give more attention to those Success factors in CMP practices. The experts identified possible relationships between the Success factors and the CMP stages inputting a cell value of 1 If a Factor affects a stage to influence the achievement of a performance indicator, (hence there is a relationship) and 0 where there is no relationship. Then the information gathered was used as input to develop the interpretive matrix with experts defining and explaining the relationships between a Factor and the CMP stage, where the cell value was 1 . The interpretive matrix (Table 2) was developed based on the feedback from experts and provides an understanding of how a Factor affects CMP stages in achieving the performances indicators. Further, the dominating interaction matrix is developed based on the analysis of the interactions of the 12 success factors with respect to the CMP stages and outcomes in a pairwise manner. As part of the process, one Factor is compared with another Factor with respect to each CMP stage and its pointer hence, evaluating how a Factor say F1 is more important in achieving P1 than another Factor say F2. The dominance matrix, as depicted in Table 4 is then developed from the analysis of the interaction matrix to ascertain the ranking of a Factor. This ranking is based on a computation of the sum rows and columns to give the total number of cases in which a ranking Factor dominates or is being dominated by all other ranking Success factors.

\subsection{Interpretive ranking model}

Figure 2 shows the interpretive ranking model developed using the ranks obtained from the dominance matrix in Table 3. There are eleven Factor rankings, as shown in the model arranged in descending order. For each Factor, its dominating number and the number being dominated are provided in the small brackets in the model. The arrows in the model represent cases in which a particular ranking Factor dominates another ranking Factor in a CMP stage. The rankings of the Success factors in descending order include competent design team ranking $\left(1^{\text {st }}\right)$, competent contractor's team $\left(2^{\text {nd }}\right)$, and effective team collaboration and commitment ranking $\left(3^{\text {rd }}\right)$. Early contractor involvement and effective project planning, and supervision was ranked $4^{\text {th }}$, clear and well-detailed client brief $5^{\text {th }}$, detailed designs and specifications ranked $6^{\text {th }}$. 
Adequate and timely funding for cash flow was $7^{\text {th }}$, and political stability was $8^{\text {th }}$. Timely resolution of land compensation issues ranked $9^{\text {th }}$, economic stability ranked $10^{\text {th }}$, and lastly, stable weather conditions ranked $11^{\text {th }}$. Table 5 provides further clarity on the ranking of the Success factors with respect to each CMP stage and its performance indicator.

\subsection{Interpretive ranking model validation}

The next stage of this research involved validating the interpretive ranking model with the eight domain experts highlighted earlier. Such a validation enhances the credibility and acceptance of the model developed through the IRP technique. The ranks obtained from the dominance matrix were validated through a confidence-building and structured walkthrough of the variables. The purpose of the validation was for participants to assess the clarity and appropriateness of the model structure, the interpretation of the interactions and that the assessment of paired comparison was appropriate, and the summation of all the net dominances for all the variables is zero. The expert's feedback on the factor relationships, rankings and criticality with respect to CMP stage outcomes was elicited through focus group discussions. Experts' confirmed that the content, structure and ranks were correct. They also confirmed that the supporting interpretation in Table 4 for each stage of the process was particularly beneficial and reflected the critical factors specifically needed to be considered at each stage for successful implementation and outcomes.

\subsection{DISCUSSION OF FINDINGS}

The results showed that some of the identified CSFs from the literature are also influential for CMP implementation in PHP settings, with five Success factors most favourably rated critical. These are competent design team, competent contractor and site management team, effective collaboration and commitment, early contractor involvement, and effective planning and site supervision. The IRP confirms these five Success factors as possessing a significant influence on at least two CMP stages. This result establishes that team related CSFs do have a higher influence on efficient CMP implementation in PHPs than project environment-related Success factors corroborating findings from earlier studies (Olawale and Sun, 2013; Kog and Log, 2012; Obi et al., (2017). Key observations show consistency of some Success factors and variance in the ranking of others at various CMP stages, demonstrating the perceived influence of each Factor as a project progresses. This finding is vital because the individual ranking, as shown in Table 6, highlights the perceived dominance of specific Success factors within each of the 
stages and project sponsors, managers and project professionals may be particularly interested in the implications of this result.

\subsection{Setting Stage}

To achieve realistic project target cost at the setting stage, the IRP findings highlighted a high dominance of Factors: F4, F1, F7, F5, and F6, in order of ranking influence. The results underscore the criticality of professionals' competence, their integration and collaboration and a well-detailed client project brief to successfully set project target costs based on market value, and client and end-user affordability as this stage. Th. This finding aligns with aspects of the literature that advocate the need for competent professionals (Olawale and Sun, 2013; Enshassi et al. 2013; Morad and El Sayegh 2016). It is during this early stage of CMP in PHPs that the greatest influence on capital costs and project outcomes are possible. F4 and F5 indicate that the competency of PT professionals is crucial at this stage. The professionals are required to possess appropriate academic and professional qualifications appropriate to their engaged role, experience in large projects or PHPs and skillsets that support collaborative practices. In addition, IT capabilities needed for managing and optimising cost determining activities are crucial. F4 and F5 promotes F7. F7- Effective collaborative practices and commitment between and within the key stakeholders' teams is crucial to develop and evaluate the client's project brief at this stage. F7 promotes mutual trust within PT required to support client objectives on the project (Smith, 2016; Asiedu et al., 2017). Surprisingly F6 is ranked relatively high within this stage. Considering the client and end-users affordability challenges and tight resources that characterise PHPs, the potential benefit of F6 at this stage is crucial. Knowledge transfer on successes and failures of previous projects is a vital early step for any project. F6 exploits a contractor's specialist knowledge of construction processes to the benefit of the design and cost management process (Laryea and Watermeyer, 2016). Prior studies have articulated that very few PHP are delivered successfully and are ten times more likely to fail where there is poor integration of the contractor at the early stages of the project (Zimina et al., 2012; Jacomit and Granja 2011). With F6, the design team can draw lessons from contractors' experiences on previous PHPs, and apply these lessons to enable effective target cost determination and also mitigate detrimental cost management actions.

\subsection{Planning Stage:}

To achieve viable elemental cost targets at the planning stage, findings highlight a high dominance of Success factors: F4, F7, F5, F6, F2 and F1, in order of ranking influence. These 
underscore PT professional competence, team collaboration and integration, accurate design and cost information, as critical in driving the innovation necessary to establish a realistic elemental cost targets during the concept and detailed design phases of PHPs. F4- design experts need to provide high quality of designs and cost managers, are required to engage their technical expertise in evaluating cost-effectiveness of the PHPs design stage and interpret the cost implications and information facilitating viable estimates for each element of the project at the planning stage. F7- is useful for effective evaluation of design solutions required to keep the costs within the overall target cost. The cost analysis of previous similar projects, including available project drawings should be compared and collaboratively assessed to ensure elemental target costs are viable and conform to the overall project costs. F5 provides additional knowledge and resources to the design team relevant to support effective strategic decisions impacting of design economics and cost. Through F6- knowledge transfer from experience on previous projects, is obtained earlier in the process and additional resources support can be exploited from the contractor's team for cost planning purposes. Cost information from previous PHPs, and in-house cost models made available by contractor team members can assist the design team in developing cost-effective designs from which realistic elemental costs can be determined. Consequently, F2 - detailed and accurate design and cost information on PHPs can be appropriately developed. Accurate and well-detailed drawings and cost data mitigates detrimental cost management actions such as cost-related wastes that may results from errors in resources quantities (Olawale and Sun 2010; Kog and Loh 2012; Enshassi et al. 2013; Waziri 2012). F1, provides a guide to confirm designs and cost implications on the overall client Budget.

\subsection{Budgeting Stage:}

To assure full control of the project cost within agreed tolerances during the construction stage a viable operational cost baseline is required (Asworth, 2010). To produce realistic operational cost baseline findings highlight a high dominance of Factor F4, F5, F6, F3, and F7 in order of ranking influence. It underscores the criticality of competent professionals, early team integration, effective construction planning and management and team collaboration and commitment. Similar to the setting and planning stages, F4 and F5 are highly ranked at this stage. PT professionals are require to possess relevant capabilities to provide and expertly plan construction activities employing necessary IT and managerial actions to align the operational cost baseline to elemental cost targets. A realistic operational cost baseline, is required for effective real-time monitoring can be proactive during construction (PMI, 2013; Asiedu et al. 
2017). Therefore, effective construction planning and management (F3) is critical in budgeting and documenting project deliverables. F3 is required to establish a logical mechanism to plan and allocate project resources on the specified project timeline. The work and cost breakdown plan is used to produce the operational cost baseline. The relevant experience-based contributions and resources of F6 is required to support effective planning of activities and their associated costs to establish a viable operational cost baseline for construction. Nevertheless, effective communication and collaborative working (F7) is required of the team to efficiently develop activity and resource work plans. PT professionals must commit to the shared goal of developing a viable operational baseline by willingly brainstorming solutions and arriving at consensus about allocations of the various activities and associated costs in the cost baseline.

\subsection{Control stage:}

To deliver positive PHP cost performance index, findings highlight a high dominance of Factors F3, F5, F4, F8, and F7, in order of ranking influence to achieve effective cost performance index. Other factors include F2, F9, F12 and F11. The relevance of effective construction planning and management (F3) is crucial at this stage, to ensure activities comply with the required cost baseline. F3 allows proactive and real-time monitoring of work progress, including site resources control (PMI, 2013; Cheng, 2014). Appropriate tools for construction planning and management is required to coordinate and monitor project activities in PHPs. F5 (competent site management team) is requires appropriate skillset to undertake effective day to day planning, tracking and control of construction costs against the project budget to avoid cost overruns. F4 expertise is required to support and ensure contractors' performances cost determining activities during construction. F8- available and timely flow of funds in PHPs is a key client's obligation (Saisi et al., 2015) to assist the PTs especially contractors maintain the necessary workflow onsite. F8 is required for effective cash flow to enable contractor deliver the project (Usman et al., 2016; Asiedu et al., 2017). The lack of working capital to support daily site activities can be a problem in PHPs considering bureaucracy that could be associated with processing contractor payments. Often, the funding agencies are a separate institution from the housing agencies/ authorities, and the inefficiencies and bureaucracy of the funding agencies may affect cash flow to the project (Obi et al., 2017). Thus the need for appropriate strategies is employed to ensure that funding is timely released during critical times of work activities in line with the work programme to ensure cost benefits (earned value) are realised. Other factors F9 -F12 though not highlighted as critical also support the successful outcomes 
of the CMP. F9 eliminates the possibility of negative fluctuations resulting from rising market prices. F10 supports a conducive work environment mitigating bureaucratic bottlenecks, F11, mitigates idle time and material damage for adverse weather conditions and F12 supports the social safety of the workforce on site.

In summary, the finding of this study has clear implications for the project sponsor, manager and the PT when assessing how to achieving performance indicators and how effectively the project would meet cost performances objectives. These include:

- The need for Government Project departments to adopt procurement routes or contracts that facilitates engagement of the services of the contractor at the earliest stage of the project to support the CMP.

- The need for the Project managers to create an atmosphere where mutual trust and commitment can thrive within the PT as this is essential to support effective collaboration.

- The need for appropriate competency-based measures to map the competencies ( Knowledge skillset and experience) of PT professionals to the appropriate job specifications of their teams' and to ascertain the capability to engage in PHP projects

- The need for Periodic workshops and training to discuss expectations and the roles expected of various parties to deliver CMP outcomes at each stage. This will help to set the team in the required mindset and increase the chances of achieving successful cost management practice and outcomes on the project.

- The need for collaborative digital platforms and tools to facilitate effective communication channels. This is necessary for effective information sharing, throughout the project stages, including planning and control activities useful to the CMP in PHP settings.

\section{CONCLUSION}

This paper presented a discussion on the CMP CSFs. The research focused specifically on the factors underlying effective CMP implementation and outcomes for project managers and PTs operating in the PHPs sector. The study argues the vagueness of a generic investigation to only identify Success factors without examining their association with the CMP stages. In doing so, it outlined the research methodological approach adopted for developing the interactions of the critical factors for promoting successful CMP implementation and outcome within PHP 
settings. This included three stages; where: stage 1 presented findings from the literature, highlighting 54 generic CSFs affecting construction project cost performances. Stage two presented the findings from brainstorming sessions. The sessions helped refined the success factors (within the PHP context) and established the influence of each Factor for different CMP outcomes. The final stage (Stage 3) employed the expertise of 8 domain experts to test and validate findings from the IRP model. Findings were articulated through a process factor IRP model which identified five CSFs, competent design team professionals, competent contractor site management team, effective collaborative practices, early contractor team involvement, and effective planning and supervision, all of which are mapped against the CMP stages and outcomes. The process-factor model provides clear guidance and direction into the practical stages and factors needed for PTs to maximise their cost management practices on PHPs. The outcome of which enables project managers and government project departments' and construction organisations to evaluate requirements for engaging design and contracting teams for PHPs.

This paper also contributes to the body of knowledge in project cost management in construction.

- The study outcome is relevant to provide Project Managers and PT with a Process-Factor analysis on how best to manage the CMP towards successful outcomes and uniquely contributes to the knowledge of the CSFs for cost management practices in PHPs settings

- It is the first study to apply the IRP method to explore the relationship between Success factors in the context of CMP stages and outcomes.

- The performance pointers indicated in the model can be benchmarked across PHPs operational framework for monitoring cost efficiency at each CMP stages to aid cost standardisation

- While this study findings were developed for the PHP sector; methodologically, there are a number of areas that are directly transferable, including large construction projects.

- The research also documents well-cited cost management Success factors across literature and methodological process for investigations using qualitative and interpretive based techniques. These techniques can be transferred to evaluate Success factors for cost management in other project settings such as offsite construction based PHPs.

Further studies may evaluate the quantitative impact of the underlying Success factors identified with respect to each CMP stage and the overall cost performances comparing PHPs 
in developed and developing settings. Also, an examination of Success factors for cost management process during the maintenance and demolition/deconstruction stages of PHP project life cycle could be further investigated. One of the limitations of this research is that it does not present an application of the model in a real-life scenario. Therefore future research should evaluate the practical implications of the ranking model through real-world case studies.

\section{REFERENCES}

Adinyira, E., Botchway, E. and Kwofie, T.E. (2012), "Determining critical project success criteria for public housing building projects (PHBPS) in Ghana", Engineering Mgt Research, Vol. 1 No.2, pp. 122

Ahadzie, D. K., Proverbs, D. G., and Sarkodie-Poku, I. (2014), "Competencies required of project managers at the design phase of mass house building projects", International Journal of Project Management, Vol. 32 No. 6, pp. 958-969.

Agrawal, S., Mehra, S. and Siegel, P. (1998), "Cost management system: an operational overview”, Managerial Finance, Vol. 24 No. 1, pp. 60-78.

Adabre, M. A., and Chan, A. P. (2019). "The ends required to justify the means for sustainable affordable housing: A review on critical success criteria”. Sustainable Development, Vol. 27 No 4, pp 781-794.

Ashworth, A. (2015), Cost Studies of Buildings: 6th Ed. Pearson Prentice Hall, Harlow, U.K. Asiedu, R.O., Adaku, E. and Owusu-Manu, D.G., (2017), "Beyond the causes: Rethinking mitigating measures to avert cost and time overruns in construction projects", Journal of Construction Innovation, Vol. 27 No.3, pp. 363-380.

Chen, Y., Zhang, Y., Liu, J. and Mo, P. (2012), "Interrelationships among critical success factors of construction projects based on the structural equation model”, Journal of Mgt. in Engineering, Vol. 28 No. 3, pp. 243-251.

Cheng, Y. M. (2014). "An exploration into cost-influencing factors on construction projects", Int J. of Project Mgt, Vol. 32 No. 5, pp. 850-860.

Denzin, N. K., and Lincoln, Y. S. (2011), The Sage handbook of qualitative research, Sage, London, U.K

Doloi, H. (2013), Cost overruns and failure in project management: Understanding the roles of key stakeholders in construction projects. Journal of construction engineering and management, Vol. 139 N0. 3, pp.267-279. 
Enshassi, A., Mohamed, S. and Abdel-Hadi, M. (2013), "Factors affecting the accuracy of pretender cost estimate in the Gaza Strip". Journal of Construction in Dev Countries, Vol. 18 No. 1,pp.73-94.

Fellows, R. F., and Liu, A. M. (2015), Research methods for construction John Wiley \& Sons, Sussex, U.K

Haleem, A., Sushil, Qadri. M. A., and Kumar, S. (2012), “Analysis of critical success factors of world-class manufacturing practices: an application of interpretive structural modelling and interpretive ranking process", Production Planning and Control, Vol. 23 No. 10-11, pp. $722-734$.

Jacomit, A. M., and Granja, A. D. (2011), “An investigation into the adoption of target costing on Brazilian public social housing projects", Architectural Engineering and Design Management, Vol. 7, No. 2, pp. 113-127.

Johnson, H.T. and Kaplan, R.S., (1987). "The rise and fall of management accounting", IEEE Engineering Management Review, Vol.15, No. 3, pp. 36-44.

Kern, A. P., and Formoso, C. T. (2006), "A model for integrating cost management and production planning and control in construction. J. of Financial Mgt of Property and Construction, Vol. 11 No. 2, pp. 75-90.

Kirkham, R. (2015), Ferry and Brandon's cost planning of buildings 9th ed., John Wiley \& Sons, Sussex, U.K

Kog, Y.C. and Loh, P.K. (2012), "Critical success factors for different components of construction projects". Journal of Construction Engineering and Management, Vol.138, No. 4, pp. $520-528$

Liu, L. and Zhu, K., (2007), "Improving cost estimates of construction projects using phased cost factors". Journal of Construction Engineering and Management, Vo. 133 No. 1, pp. 91-95.

Laryea, S., and Watermeyer, R. (2016), "Early contractor involvement in framework contracts", in proceedings of the Institution of Civil Engineers-Management, Procurement and Law, Vol 169, No. 1, pp. 4-16.

Luthra, S., Garg, D., and Haleem, A. (2015), "Critical success factors of green supply chain management for achieving sustainability in Indian automobile industry". Production Planning \& Control, 26(5), 339-362. 
Mitchell, D. (2012), "5D BIM: creating cost certainty and better buildings", in Proceedings of the RICS Cobra Conference in Las Vegas 2012, Nevada USA available at: https://www.irbnet.de/daten/iconda/CIB_DC27547.pdf (accessed 20 September 2019).

Morad, M. and El-Sayegh, S.M., (2016), "Use of Earned Value Management in the UAE Construction Industry", in Proc., of 2016 International Conference on Industrial Engineering, Management Science and Application (ICIMSA), Jeju, South Korea 2016, IEEE pp. 1-5.

Iqbal, M. Z., Könings, K. D., Al-Eraky, M., AlSheikh, M. H., and van Merrienboer, J. J. (2020). "Development of an entrustable professional activities (EPAs) framework for small group facilitators through a participatory design approach”. Medical Education Online, Vol. 25 No. 1, pp. 1-10

Obi, L.I., Arif, M., and Kulonda, D.J., (2017), "Prioritising cost management system considerations for Nigerian housing projects." Journal of Financial Management of Property and Construction, Vol. 22 No. 2, pp.135-153.

Odusami, K.T. and Onukwube, H.N. (2008). "Factors affecting the accuracy of a pre-tender cost estimate in Nigeria" Cost engineering, Vol. 50, No. 9, pp. 32-35.

Okoye, P. U., Ngwu, C., and Ugochukwu, S. C. (2015), "Evaluation of management challenges facing construction practice in Nigeria" International Journal of Application or Innovation in Engineering \& Management, Vol. 4, No. 1, pp. 19-28

Olawale, Y. A., and Sun, M. (2010), “Cost and time control of construction projects: inhibiting factors and mitigating measures in practice"Construction Management and Economics, Vol. 28, No. 5, pp. 509-526.

Olawale, Y., and Sun, M. (2013). "PCIM: Project control and inhibiting-factors management model” Journal of Mgt. in Eng.,10.1061/(ASCE)ME.1943-5479.0000125

Nyumba, T., Wilson, K., Derrick, C. J., and Mukherjee, N. (2018). "The use of focus group discussion methodology: Insights from two decades of application in conservation". Methods in Ecology and evolution, Vol. 9 No. 1,pp. 20-32.

Project Management Institute (PMI), (2013), "Guide to the Project Management Body of Knowledge, 5th ed.”, Project Management Institute, Newtown Square, PA, available at: http://dinus.ac.id/repository/docs/ajar/PMBOKGuide_5th_Ed.pdf(accessed September 2019). 
Royal Institution of Chartered Surveyors (RICS), (2012), "New Rules of Measurement-NRM 1: Order of Cost Estimating and Cost Planning for Capital Building Works". London: Royal Institution of Chartered Surveyors.

Sinesilassie, E. G., Tripathi, K. K., Tabish, S. Z. S., and Jha, K. N. (2019). Modeling success factors for public construction projects with the SEM approach: engineer's perspective. Engineering, Construction and Architectural Management. 26(10), pp. 24102431

Shrestha, P. P., and Mani, N. (2013), "Impact of design cost on project performance of designbid-build road projects". Journal of Mgt. in Engineering, Vol 30, No. 3, pp. 04014007-18

Smith, P. (2014), "Project Cost Management-Global Issues and Challenges." Procedia-Social and Behavioral Sciences, Vol. 119, pp. 485-494.

Smith, P., (2016), "Project cost management with 5D BIM", Procedia-Social and Behavioral Sciences, 226, pp.193-200.

Sourani A. and Sohail, M. (2015) "The Delphi Method: Review and Use in Construction Management Research", International Journal of Construction Education and Research, Vol 11 No. 1, pp 54-76,

Sushil, (2009), "Interpretive ranking process", Global Journal of Flexible Systems Management, Vol. 10 No.4, pp. 1-10.

Tang, W. (2005), “Cost management for building contractors in Hong Kong”, MSc dissertation. University of Hong Kong, available at: https://doi.org/10.5353/th_b3160121 (accessed 25th July 2019)

Trost, S.M. and Oberlender, G.D., (2003), "Predicting the accuracy of early cost estimates using factor analysis and multivariate regression.” Journal of Construction Engineering and Management, Vol 129, No. 2, pp. 198-204.

United Nations Human Settlements Programme (UN-Habitat) (2011), “Affordable land and housing in Africa”, available at: http://mirror.unhabitat.org/pmss/listItemDetails.aspx?publicationID=3376 (accessed Sept. 10, 2019)

Waziri (2012), “The effects of control factors on the accuracy of pretender cost estimating in Northeastern Nigeria, Continental J. Environmental Design and Management, Vol. 2 pp. 33-39 
Wilson, C. (2013). Brainstorming and beyond: a user-centered design method. Elsevier, Oxford, UK.

Wuni, I.Y. and Shen, G.Q., (2020). Critical success factors for management of the early stages of prefabricated prefinished volumetric construction project life cycle. Engineering, Construction and Architectural Management.

Zimina, D., Ballard, G., and Pasquire, C. (2012), "Target value design: using collaboration and a lean approach to reduce construction cost." Construction Management and Economics, Vol. 30 No. 5, pp. 383-398.

Zhang, L.L., Narkhede, B.E. and Chaple, A.P., (2017), "Interpretive ranking process-based lean manufacturing barrier evaluation”. In 2017 IEEE International Conference on Industrial Engineering and Engineering Management (IEEM)in Singapore, 2017, IEEE pp. 15911595 
Step 1: Establishing ranking (Success Drivers) and reference (CMP stage and their performance pointers) variables - expert dependent

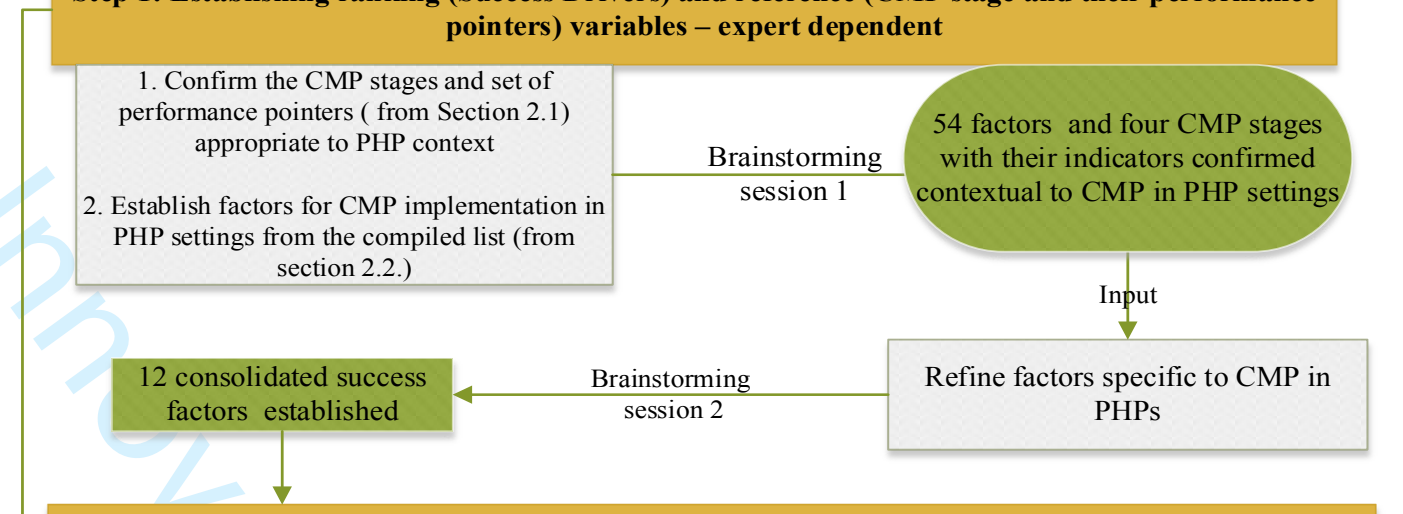

Step 2: Establish contextual relationship between ranking and reference variables and develop a develop a cross interaction matrix - Expert dependent

Experts to identifying possible contextual relationships between ranking variables using " 1 " where a relationship is possible and " 0 " for no relationship

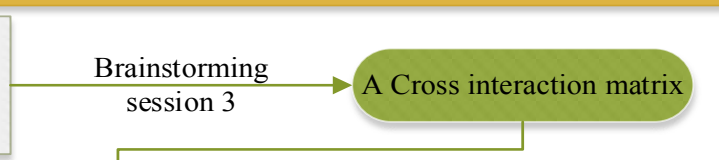

\section{Step 3: Interpretation of drivers interactions to develop interpretive matrix - (Expert dependent)}

Expert to interpret interactions of the

relationship between the success factors and each CMP stage and its performance indicator

\section{Brainstorming} session 4

An interpretive matrix.

Step 4: Pairwise comparison of ranking variables with respect to reference variables (Expert dependent)

Expert to identify dominating interactions between the success factors with respect to each CMP stage and its performance indicator
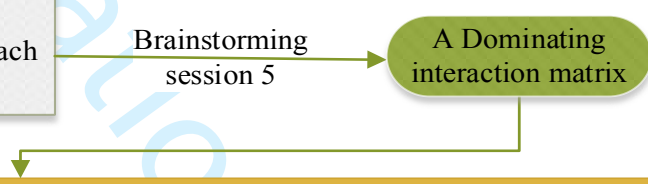

Step 5: Computation of ranks
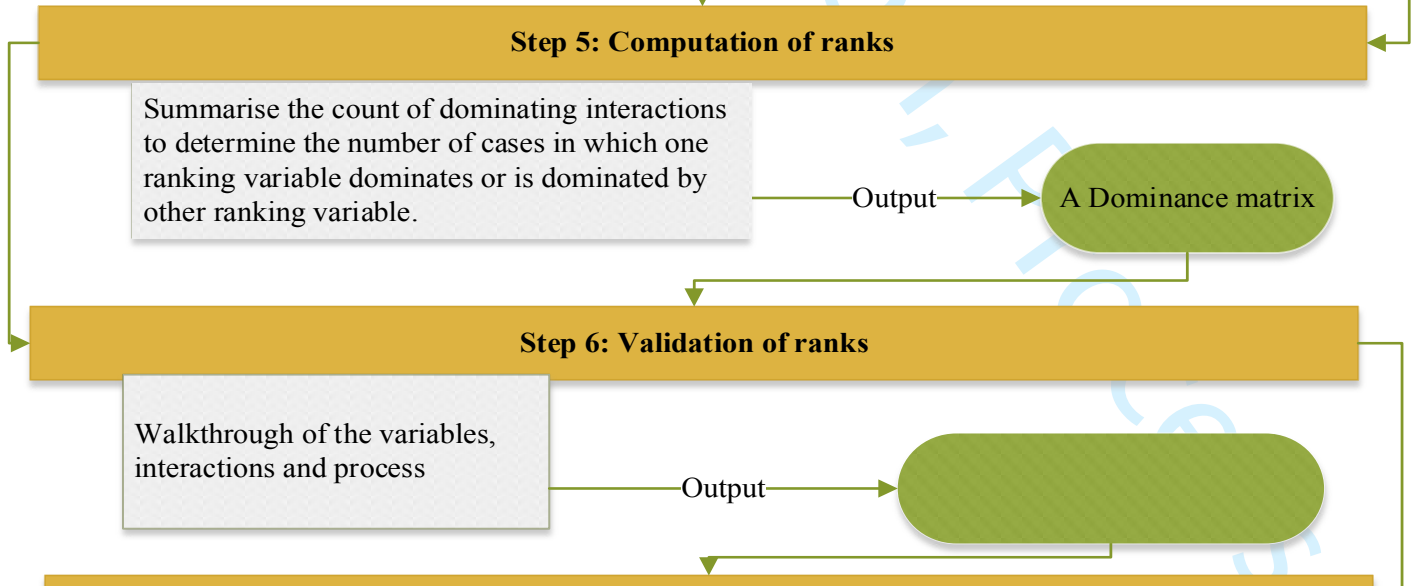

Step 7: Graphical display dominance relationship and interpretation

Design and develop the graphical relationships between the success factors with respect to the CMP and performance indicators

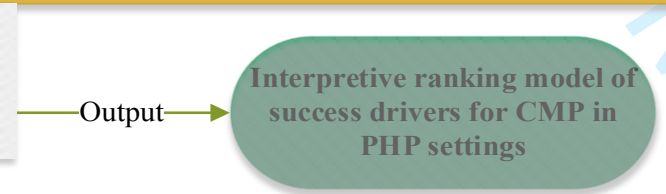

Figure 1: IRP methodological approach for the study 


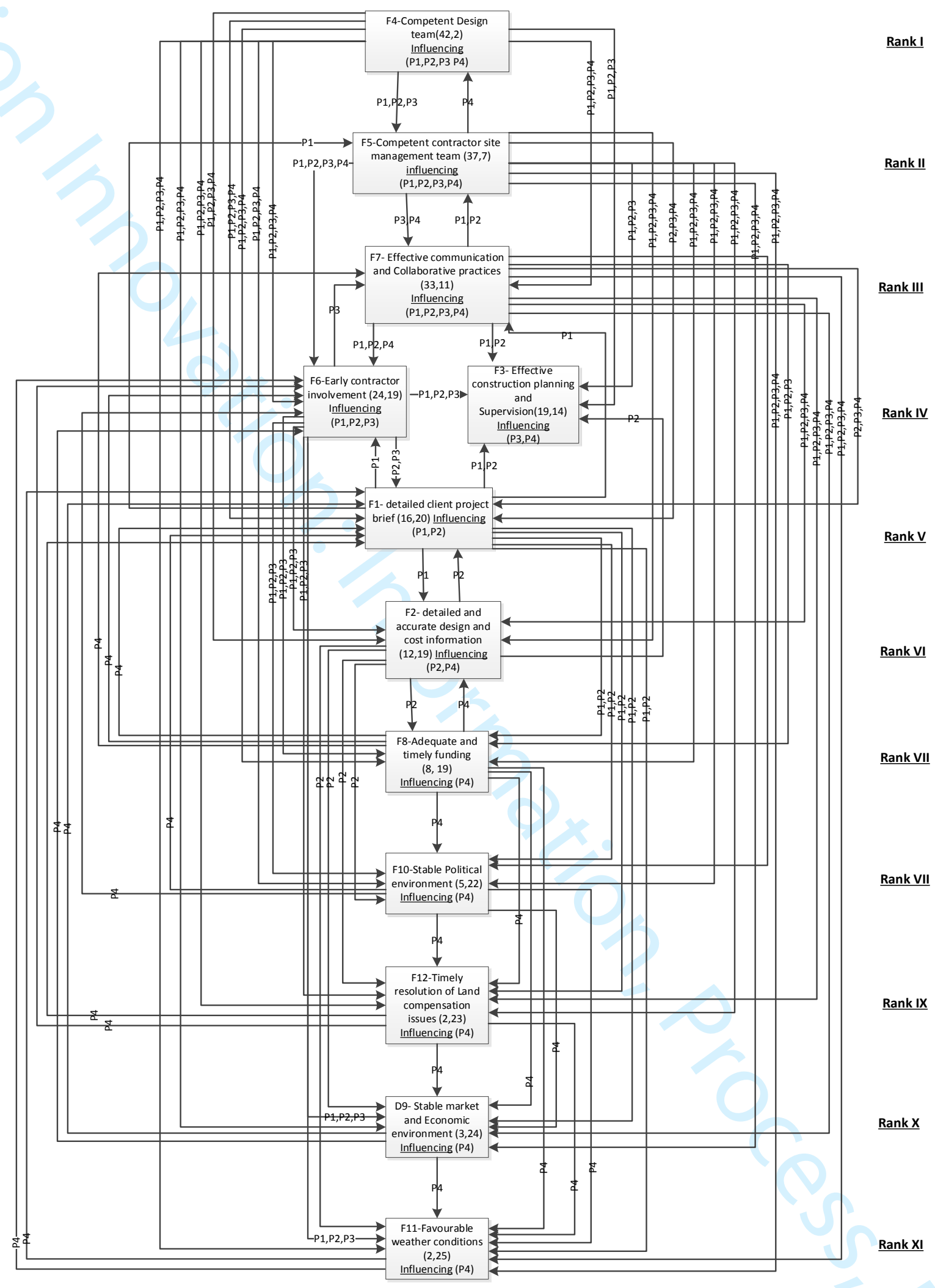

Figure 2: Interpretive ranking model of process factors 


\section{Table 1: Success Factors for Cost performances and management}

\begin{tabular}{|c|c|}
\hline Variables & Literature \\
\hline $\begin{array}{ll}\text { 1. } & \text { Project managers experience } \\
\text { 2. } & \text { Knowledge and competency } \\
\text { 3. } & \text { Team technical and IT capabilities }\end{array}$ & $\begin{array}{l}\text { Kog and Loh (2012) Enshassi et al. (2013) Morad and El-Sayegh, (2016) Smith (2016), } \\
\text { Lindhard and Larsen, 2016) Obi et al. (2017). Sinesilassie et al. (2018) Wuni and Shen, (2020) }\end{array}$ \\
\hline $\begin{array}{l}\text { 4. Management and technical capabilities of } \\
\text { the client organisation }\end{array}$ & $\begin{array}{l}\text { Morad and El-Sayegh, (2016) Obi et al. (2017) Sinesilassie et al. (2018), Wuni and Shen, } \\
(2020)\end{array}$ \\
\hline $\begin{array}{ll}\text { 5. Project team experience, } \\
\text { 6. Team competencies and capabilities } \\
\text { 7. Experience and skill level of the consultant } \\
\text { 8. Expertise of consultants } \\
\text { 9. Experience of project type }\end{array}$ & $\begin{array}{l}\text { Trost and Oberlender (2003) Liu and Zhu (2007) Odusami, and onukwube (2008) Enshassi et } \\
\text { al. (2013) Waziri (2012) Okoye et al., (2015) Morad and El-Sayegh, (2016) Asiedu et al. } \\
\text { (2017), Obi et al. (2017) Tang (2005) Wuni and Shen, (2020) }\end{array}$ \\
\hline $\begin{array}{l}\text { 10. Contractor's team capabilities and } \\
\text { 11. Contractor team experience, } \\
\text { 12. Effective subcontractor and supply chain } \\
\text { management }\end{array}$ & $\begin{array}{l}\text { Trost and Oberlender (2003) Liu and Zhu (2007) Odusami, and Onukwube (2008) Enshassi et } \\
\text { al. (2013) Waziri (2012) Cheng, (2014) Okoye et al., (2015) Asiedu et al. (2017) Obi et al. } \\
\text { (2017). Sinesilassie et al. (2018), Wuni and Shen, (2020) }\end{array}$ \\
\hline $\begin{array}{l}\text { 13. Communication, } \\
\text { 14. Quality of information and flow } \\
\text { coordination, collaboration, } \\
\text { 15. Trust and commitment by team members }\end{array}$ & $\begin{array}{l}\text { Tang (2005) Liu and Zhu (2007) Odusami,and Onukwube (2008) Olawale and Sun (2010) Kog } \\
\text { and Loh (2012) Enshassi et al (2013) Waziri (2012) Cheng, (2014) Okoye et al, (2015) Morad } \\
\text { and El-Sayegh, (2016)Smith 2016 Lindhard and Larsen, } 2016 \text { Asiedu et al. (2017) Obi et al. } \\
\text { (2017) Sinesilassie et al. (2018), Wuni and Shen, (2020) }\end{array}$ \\
\hline $\begin{array}{l}\text { 16. Top management support } \\
\text { 17. Trust and buyin from senior management }\end{array}$ & Morad and El-Sayegh, (2016) Lindhard and Larsen, (2016) Sinesilassie et al. (2018) \\
\hline 18. Team alignment, & Liu and Zhu (2007) Waziri (2012) Obi et al. (2017) \\
\hline 19. Project procurement route & Tang (2005) Liu and Zhu (2007)Odusami, and Onukwube (2008)Waziri (2012) Cheng, (2014) \\
\hline $\begin{array}{l}\text { 20. Early contractor involvement and advice } \\
\text { 21. Early integration of project team }\end{array}$ & $\begin{array}{l}\text { Tang (2005) Liu and Zhu (2007) Odusami, and Onukwube (2008) Waziri (2012), Okoye } \\
\text { (2015) Wuni and Shen, (2020) }\end{array}$ \\
\hline $\begin{array}{l}\text { 22. Market conditions } \\
\text { 23. Currency exchange fluctuation }\end{array}$ & Enshassi et al. (2013) Liu and Zhu (2007) Odusami, and Onukwube (2008) Cheng, (2014) \\
\hline 24. Borders closure and blockade & Enshassi et al. (2013) \\
\hline $\begin{array}{ll}\text { 25. } & \text { Favourable Labour climate } \\
\text { 26. } & \text { Bidding climate }\end{array}$ & Trost and Oberlender (2003) Odusami, and Onukwube (2008) \\
\hline $\begin{array}{l}\text { 27. Material cost and } \\
\text { 28. Material availability }\end{array}$ & Tang (2005) and Enshassi et al. (2013) Cheng, (2014) \\
\hline $\begin{array}{l}\text { 29. Detailed drawings and specification } \\
\text { 30. Extent of completion of pre-contract design, } \\
\text { 31. Complexity of design }\end{array}$ & $\begin{array}{l}\text { Odusami, and Onukwube (2008) Olawale and Sun (2010) Kog and Loh (2012) Enshassi et al. } \\
\text { (2013) Cheng, (2014) Lindhard and Larsen, 2016Asiedu et al. (2017) Obi et al. (2017), } \\
\text { Onukwube (2008), Wuni and Shen, (2020) }\end{array}$ \\
\hline 32. Accurate cost data & $\begin{array}{l}\text { Trost and Oberlender (2003), Tang (2005) Liu and Zhu (2007) Enshassi et al. (2013) Waziri } \\
\text { (2012) and Smith } 2016\end{array}$ \\
\hline $\begin{array}{ll}\text { 33. } & \text { Process design } \\
34 . & \text { Estimating process } \\
35 . & \text { Estimating design } \\
\text { 36. } & \text { Estimating methodology, }\end{array}$ & Trost and Oberlender (2003), Liu and Zhu (2007), Waziri (2012) \\
\hline $\begin{array}{l}\text { 37. } \\
\text { 38. Effective planning and resource control } \\
\text { 39. Effective expenditure control } \\
\text { 40. } \text { Monitoring and feedback }\end{array}$ & $\begin{array}{l}\text { Olawale and Sun (2010) Asiedu et al. (2017) Obi et al. (2017). Sinesilassie et al. (2019) Tang } \\
\text { (2005) Cheng, (2014), Wuni and Shen, (2020) }\end{array}$ \\
\hline 41. Sufficient time for estimating & Trost and Oberlender (2003) Tang (2005) Olawale and Sun (2010) \\
\hline $\begin{array}{l}\text { 42. Risk identification and management } \\
\text { 43. Claims management } \\
\text { 44. Effective determination of contingency } \\
\text { allowance }\end{array}$ & Olawale and Sun (2010), Tang (2005) \\
\hline 45. Clear contract conditions & Waziri (2012) and Smith (2016) \\
\hline $\begin{array}{ll}\text { 46. } & \text { Clear project objectives } \\
\text { 47. } & \text { Project requirements }\end{array}$ & $\begin{array}{l}\text { Trost and Oberlender (2003), Tang (2005) Liu and Zhu (2007), Olawale and Sun (2010) } \\
\text { Waziri (2012), Cheng, (2014) Obi et al. (2017), Sinesilassie et al. (2018) }\end{array}$ \\
\hline $\begin{array}{l}\text { 48. } \text { Adequate cash flow } \\
\text { 49. } \text { Adequate funding }\end{array}$ & $\begin{array}{l}\text { Tang (2005) Olawale and Sun (2010) Kog and Loh (2012) Enshassi et al. (2013)Asiedu et al. } \\
\text { (2017) Obi et al. (2017) }\end{array}$ \\
\hline 50. Weather conditions & Liu and Zhu (2007) Cheng, (2014) and Obi et al. (2017) \\
\hline 51. Stable cultural environment & Asiedu et al. (2017) \\
\hline $\begin{array}{ll}\text { 52. } & \text { Political environment } \\
\text { 53. } & \text { Government fiscal policies }\end{array}$ & Asiedu et al. (2017) Obi et al. (2017) \\
\hline 54. Effective land compensation issues & Obi et al. (2017) \\
\hline
\end{tabular}


Table 2: Interpretive Matrix

\begin{tabular}{|c|c|c|c|c|c|}
\hline Factor & Experts decription of terms & P1 & $\mathbf{P 2}$ & $\mathbf{P 3}$ & $\mathbf{P 4}$ \\
\hline F1 & $\begin{array}{l}\text { Details on clients project expectations, availability of } \\
\text { fund, funding mechanisms, building size and } \\
\text { functions and success criteria which guides budget } \\
\text { estimate and cost planning activities }\end{array}$ & $\begin{array}{l}\text { Comprehensive } \\
\text { Information required } \\
\text { to set a target cost }\end{array}$ & $\begin{array}{l}\text { Information to enable cost plan } \\
\text { development }\end{array}$ & & \\
\hline $\mathrm{F} 2$ & $\begin{array}{l}\text { Well-designed cost-effective project drawings and } \\
\text { cost data on elements available in publish price } \\
\text { books, and in-house cost models thereby helping the } \\
\text { design team to develop cost-effective designs from } \\
\text { which realistic elemental costs can be determined }\end{array}$ & & $\begin{array}{l}\text { Better identification of work items } \\
\text { needed to define elemental cost } \\
\text { estimates and develop cost plans }\end{array}$ & & $\begin{array}{l}\text { A mechanism for waste } \\
\text { minimisation and valuation } \\
\text { of works }\end{array}$ \\
\hline F3 & $\begin{array}{l}\text { Facilitates precisely programming of site resources } \\
\text { and activities and document deliverables and } \\
\text { monitoring real-time progress of work on site }\end{array}$ & & & $\begin{array}{l}\text { A better logical mechanism to develop a } \\
\text { work breakdown structure }\end{array}$ & $\begin{array}{l}\text { A mechanism for } \\
\text { monitoring planned } \\
\text { resource alone the cost } \\
\text { baseline }\end{array}$ \\
\hline F4 & $\begin{array}{l}\text { Competency includes appropriate academic } \\
\text { qualification and professional qualifications to roles } \\
\text { assigned on the project including skill set that can } \\
\text { demonstrate managing and optimising cost } \\
\text { determining activities support collaboration and } \\
\text { information technology and resource capabilities. } \\
\text { Experience in large projects or PHPs is essential }\end{array}$ & $\begin{array}{l}\text { Experience, } \\
\text { Knowledge and skills } \\
\text { relevant to set a } \\
\text { project target cost }\end{array}$ & $\begin{array}{l}\text { Experience, Knowledge and skills } \\
\text { pertinent to support cost-effective } \\
\text { designs, interpret drawings to develop } \\
\text { a cost estimate and cost plans }\end{array}$ & $\begin{array}{l}\text { Experience, Knowledge and skills } \\
\text { relevant to establish cost aggregates and } \\
\text { operational cost baseline }\end{array}$ & $\begin{array}{l}\text { Knowledge and skills for } \\
\text { effective evaluation and } \\
\text { proactive management of } \\
\text { cost performance index }\end{array}$ \\
\hline F5 & $\begin{array}{l}\text { Team of professionals with academic and } \\
\text { professional qualifications relevant and appropriate } \\
\text { to the roles as engaged including skill set for } \\
\text { effective day to day planning, tracking and control of } \\
\text { construction costs against the project budget and } \\
\text { information technology and resource capabilities to } \\
\text { support collaboration. Experience in large projects or } \\
\text { PHPs is essential }\end{array}$ & $\begin{array}{l}\text { Knowledge and } \\
\text { experience-based } \\
\text { Information to set a } \\
\text { target cost }\end{array}$ & $\begin{array}{l}\text { Knowledge and experience-based } \\
\text { information to achieve detailed cost } \\
\text { estimates and cost plans }\end{array}$ & $\begin{array}{l}\text { Experience, Knowledge and skills } \\
\text { needed for construction planning to detail } \\
\text { cost aggregates and operational cost } \\
\text { baseline for construction }\end{array}$ & $\begin{array}{l}\text { Expertise required to } \\
\text { manage project resources } \\
\text { on-site inline with the } \\
\text { construction plan }\end{array}$ \\
\hline F6 & Early contractor involvement on the project & $\begin{array}{l}\text { Knowledge transfer } \\
\text { strategic to set a } \\
\text { realistic target cost }\end{array}$ & $\begin{array}{c}\text { Knowledge transfer for collaborative } \\
\text { practices in determining viable } \\
\text { elemental cost estimates and cost } \\
\text { plans }\end{array}$ & $\begin{array}{l}\text { Knowledge transfer Additional expertise } \\
\text { for timely construction planning and } \\
\text { detail operational cost baseline for } \\
\text { construction }\end{array}$ & \\
\hline F7 & $\begin{array}{l}\text { Ability to work as a team with high level } \\
\text { cooperation, with skillset to share information } \\
\text { appropriately and effectively to effectively } \\
\text { accomplish both individual and project-focused tasks } \\
\text { as a team member }\end{array}$ & $\begin{array}{l}\text { Better mutual trust, } \\
\text { communication and } \\
\text { teamwork to determine } \\
\text { the target cost }\end{array}$ & $\begin{array}{l}\text { Better collaborative practices to } \\
\text { develop cost-effective designs, } \\
\text { elemental cost estimate and detailed } \\
\text { cost plans }\end{array}$ & $\begin{array}{l}\text { Better collaborative practices for effective } \\
\text { construction planning and establish cost } \\
\text { aggregates and operational cost baseline } \\
\text { for construction }\end{array}$ & $\begin{array}{c}\text { Better collaborative } \\
\text { practices to improve } \\
\text { procedures for maintaining } \\
\text { positive cost performance } \\
\text { index }\end{array}$ \\
\hline F8 & $\begin{array}{l}\text { Funds available to the client for the project including } \\
\text { projected cash flow }\end{array}$ & & & 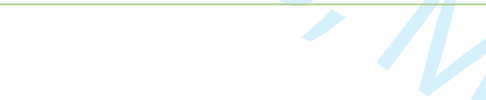 & $\begin{array}{l}\text { Facilitates adequate } \\
\text { contractor cash flow for } \\
\text { work onsite }\end{array}$ \\
\hline F9 & $\begin{array}{l}\text { Stable market and economic environment in the } \\
\text { construction market with the availability of resources }\end{array}$ & & & & $\begin{array}{l}\text { eliminates fluctuations that } \\
\text { could arise in market }\end{array}$ \\
\hline
\end{tabular}




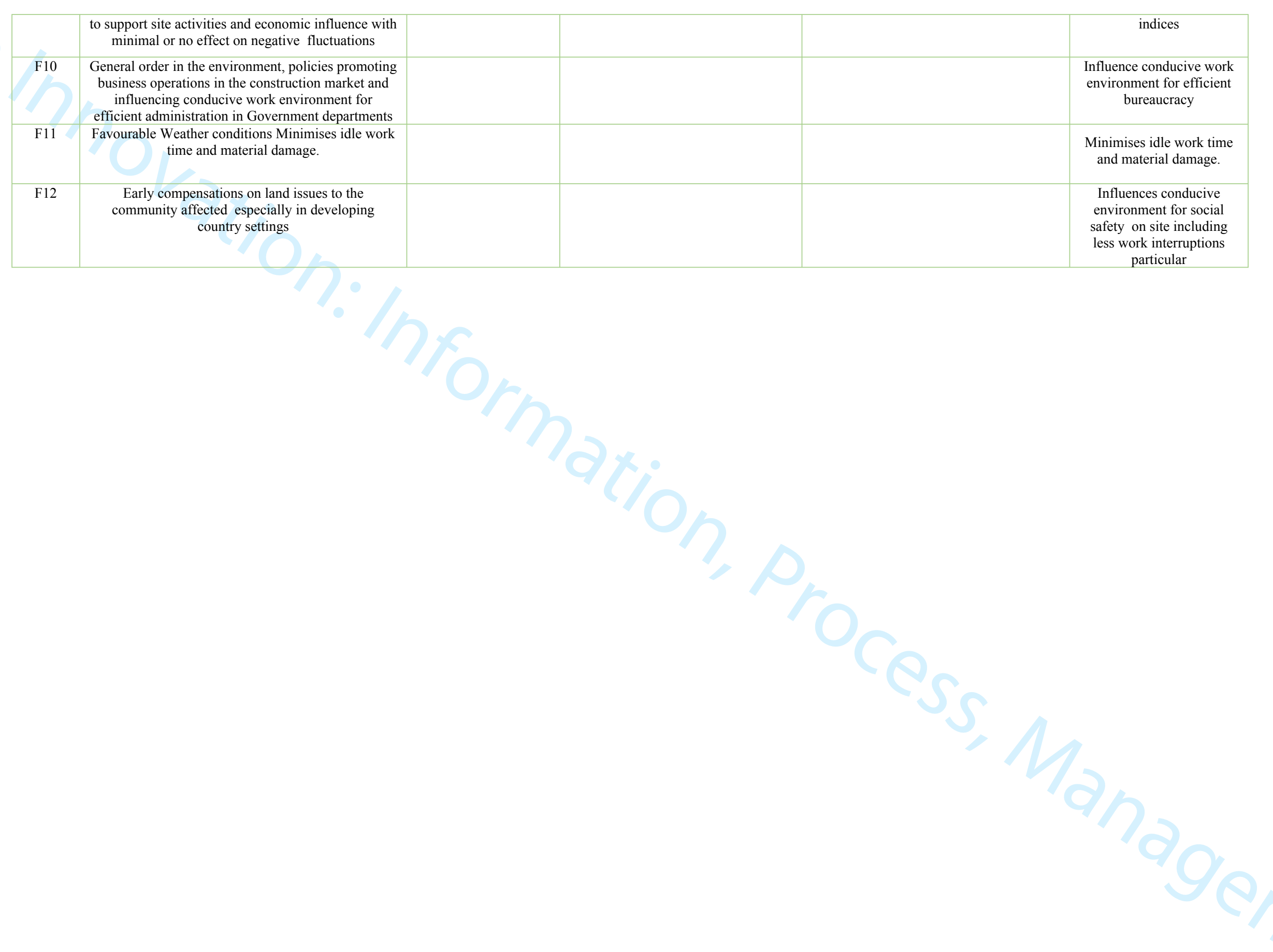


Table 3: Dominance Matrix

\begin{tabular}{|c|c|c|c|c|c|c|c|c|c|c|c|c|c|c|c|}
\hline & \multicolumn{12}{|c|}{ Factors being dominated } & \multirow{2}{*}{$\begin{array}{l}\text { Net } \\
\text { dominating } \\
\text { (D) }\end{array}$} & \multirow{2}{*}{$\begin{array}{c}\text { Net } \\
\text { dominance } \\
\text { (D-B) }\end{array}$} & \multirow[b]{2}{*}{ Rank } \\
\hline Factors & F1 & F2 & F3 & F4 & F5 & F6 & F7 & F8 & F9 & F10 & F11 & F12 & & & \\
\hline F1 & 0 & 1 & 2 & 0 & 1 & 1 & 1 & 2 & 2 & 2 & 2 & 2 & 16 & -4 & V \\
\hline $\mathrm{F} 2$ & 1 & 0 & 1 & 0 & 0 & 1 & 0 & 1 & 2 & 2 & 2 & 2 & 12 & -7 & VI \\
\hline F3 & 2 & 2 & 0 & 1 & 1 & 1 & 2 & 2 & 2 & 2 & 2 & 2 & 19 & 5 & IV \\
\hline F4 & 4 & 4 & 3 & 0 & 3 & 4 & 4 & 4 & 4 & 4 & 4 & 4 & 42 & 40 & I \\
\hline F5 & 3 & 4 & 3 & 1 & 0 & 4 & 2 & 4 & 4 & 4 & 4 & 4 & 37 & 30 & II \\
\hline F6 & 2 & 3 & 3 & 0 & 0 & 0 & 1 & 3 & 3 & 3 & 3 & 3 & 24 & 5 & IV \\
\hline F7 & 3 & 4 & 2 & 0 & 2 & 3 & 0 & 3 & 4 & 4 & 4 & 4 & 33 & 22 & III \\
\hline F8 & 1 & 1 & 0 & 0 & 0 & 1 & 1 & 0 & 1 & 1 & 1 & 1 & 8 & -11 & VII \\
\hline F9 & 1 & 0 & 0 & 0 & 0 & 1 & 0 & 0 & 0 & 0 & 1 & 0 & 3 & -21 & $\mathrm{X}$ \\
\hline F10 & 1 & 0 & 0 & 0 & 0 & 1 & 0 & 0 & 1 & 0 & 1 & 1 & 5 & -17 & VIII \\
\hline F11 & 1 & 0 & 0 & 0 & 0 & 1 & 0 & 0 & 0 & 0 & 0 & 0 & 2 & -23 & XI \\
\hline F12 & 1 & 0 & 0 & 0 & 0 & 1 & 0 & 0 & 1 & 0 & 1 & 0 & 4 & -19 & IX \\
\hline $\begin{array}{l}\text { No Being } \\
\text { dominated } \\
\text { (B) }\end{array}$ & 20 & 19 & 14 & 2 & 7 & 19 & 11 & 19 & 24 & 22 & 25 & 23 & 205 & & \\
\hline
\end{tabular}

Table 4: success Factor ranking order by CMP stage

\begin{tabular}{|c|c|c|c|c|c|c|c|c|}
\hline \multirow[t]{2}{*}{ Factor } & \multicolumn{2}{|c|}{ P1 } & \multicolumn{2}{|l|}{ P2 } & \multicolumn{2}{|l|}{ P3 } & \multicolumn{2}{|l|}{ P4 } \\
\hline & Dominates & Rank & Dominates & Rank & Dominates & Rank & Dominates & Rank \\
\hline F1 & $\begin{array}{l}\text { F2,3,5,6,7,8, } \\
9,10,11,12 \\
\end{array}$ & $2^{\text {nd }}$ & $\mathrm{F} 3,8,9,10,11,12$ & $6^{\text {th }}$ & 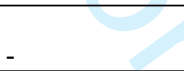 & - & 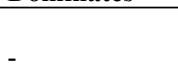 & - \\
\hline F2 & - & - & $\begin{array}{l}\mathrm{F} 1,3,8,9,10,11, \\
12\end{array}$ & $5^{\text {th }}$ & - & - & $\mathrm{F} 6,9,10,11,12$ & $6^{\text {th }}$ \\
\hline F3 & - & - & 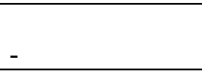 & - & $\begin{array}{l}\mathrm{F} 1,2,7,8,9,10,1 \\
1,12\end{array}$ & $4^{\text {th }}$ & $\begin{array}{l}\mathrm{F} 1,2,4,5,6,7,8, \\
9,10,11,12\end{array}$ & $1^{\text {st }}$ \\
\hline F4 & $\begin{array}{l}\text { F1,2,3,5,6,7, } \\
8,9,10,11,12\end{array}$ & $1^{\text {st }}$ & $\begin{array}{l}\mathrm{F} 1,2,3,5,6,7,8,9 \\
, 10,11,12\end{array}$ & $1^{\text {st }}$ & $\begin{array}{l}\text { F1,2,3,5,6,7,8, } \\
9,10,11,12\end{array}$ & $1^{\text {st }}$ & $\begin{array}{l}\mathrm{F} 1,2,6,7,8,9,1 \\
0,11,12\end{array}$ & $3^{\text {rd }}$ \\
\hline F5 & $\begin{array}{l}\mathrm{F} 2,3,6,8,9,1 \\
0,11,12\end{array}$ & $4^{\text {th }}$ & $\begin{array}{l}\mathrm{F} 1,2,3,6,8,9,10, \\
11,12\end{array}$ & $3^{\text {rd }}$ & $\begin{array}{l}\mathrm{F} 1,2,3,6,7,8,9, \\
10,11,12\end{array}$ & $2^{\text {nd }}$ & $\begin{array}{l}\mathrm{F} 1,2,4,6,7,8,9, \\
10,11,12\end{array}$ & $2^{\text {nd }}$ \\
\hline F6 & $\begin{array}{l}\mathrm{F} 2,3,8,9,10, \\
11,12\end{array}$ & $5^{\text {th }}$ & $\begin{array}{l}F 1,2,3,8,9,10,1 \\
1,12\end{array}$ & $4^{\text {th }}$ & $\begin{array}{l}\mathrm{F} 1,2,3,7,8,9,10 \\
11,12\end{array}$ & $3^{\text {rd }}$ & - & - \\
\hline F7 & $\begin{array}{l}\text { F2,3,5,6,8,9, } \\
10,11,12\end{array}$ & $3^{\text {rd }}$ & $\begin{array}{l}\mathrm{F} 1,2,3,5,6,8,9,1 \\
0,11,12\end{array}$ & $2^{\text {nd }}$ & $\begin{array}{l}\mathrm{F} 1,2 \\
8,9,10,11,12\end{array}$ & $5^{\text {th }}$ & $\begin{array}{l}\mathrm{F} 1,2,6,8,9,10, \\
11,12\end{array}$ & $5^{\text {th }}$ \\
\hline F8 & $x_{2}$ & - & $x^{2}$ & - & - & - & $\begin{array}{l}\mathrm{F} 1,2,6,7,9,10, \\
11,12\end{array}$ & $4^{\text {th }}$ \\
\hline F9 & - & - & - & - & - & - & $\mathrm{F} 1,6,10,11$ & $7^{\text {th }}$ \\
\hline F10 & - & - & - & - & - & - & $F 1,6,10,11,12$ & $6^{\text {th }}$ \\
\hline F11 & - & - & - & - & - & - & F1,6 & $8^{\text {th }}$ \\
\hline F12 & - & - & - & - & - & - & $\mathrm{F} 1,6,9,11$ & $7^{\text {th }}$ \\
\hline
\end{tabular}

